\title{
Tinjauan Perkembangan Keris Tangguh Ngentha-Entha Yogyakarta 1975-2015
}

\author{
Supriaswoto, SP. Gustami \\ Jurusan Kriya, Fakultas Seni Rupa, ISI Yogyakarta \\ Timbul Haryono \\ Jurusan Arkeologi, Fakultas Ilmu Budaya, Universitas Gadjah Mada Yogyakarta \\ R.M. Soedarsono \\ Jurusan Sejarah, Fakultas Ilmu Budaya, Universitas Gadjah Mada Yogyakarta
}

\begin{abstract}
Every keris possesses its own chracteristic called tangguh. There is a keris with a characteristic called tangguhngéntha-éntha which was created within the Ngéntha-ÉnthaVillage community, located to the west of Godean District, in the Sleman Regency, Yogyakarta. The prominent figure behind the establishment of that forge (besalèn) was Empu (Ironsmith) Wayang, that one day moved from Mataram Kingdom at Kartasuro to that village. In 1963, Empu Supowinangun, the heir of Empu Wayang, passed away. As a result, since that time the process of making the keris with ngéntha-énthacharacteristic was no longer conducted. In 1975 there was an effort to revitalize it and succeded. This research was conducted to investigate this revitalization by using historical method. The result of this research demonstrates that this revitalization has been conducted succesfully by two master keris-makers (empu) named Yosopangarso and Jeno Harumbrojo, after received mental endorsement and financial support from two foreigners named Garrett Solyom and Dietrick Dreschler. The two master keris-makers already passed away and today the process of making the keris with tangguh ngéntha-éntha characteristic is taken over by Empu Sungkowo, Jeno Harumbrojo's former adopted child. It is not clear who is supposed to be Sungkowo's heir. It generates a lot of worry among people of the possibility that this style of keris will decline like what happened in 1963.
\end{abstract}

Key words : keris with tangguhngéntha-énthacharacteristic, revitalization, Master Keris-makers Yosopangarso, Jeno Harumbrojo, Sungkowo.

\begin{abstract}
ABSTRAK
Setiap keris memiliki ciri tersendiri yang disebut tangguh, seperti tangguhngénthaénthayang diciptakan di lingkungan masyarakat Desa Ngéntha-Éntha. Tokoh penting yang membuat keris dengan tangguh ini adalah Empu Wayang. Pada tahun 1963, Empu Supowinangun, pewaris Empu Wayang, meninggal dunia. Akibatnya, sejak saat itu pembuatan keris dengan gaya ngéntha-éntha tidak lagi dilakukan. Pada tahun 1975 ada upaya untuk merevitalisasinya dan berhasil. Penelitian ini bermaksud meneliti revitalisasi keberadaan keris Tangguh Ngenta-entha tersebut dengan menggunakan metode historis. Hasil penelitian ini menunjukkan bahwa revitalisasi ini telah diakukan oleh dua empu keris bernama Yosopangarso dan Jeno Harumbrojo. Dewasa ini, dua orang empu keris tersebut telah meninggal dunia dan proses pembuatan keris dengan ciri-ciri tangguhngéntha-énthadiambil alih oleh Empu Sungkowo, anak angkat Empu Jeno Harumbrojo dengan metode rekonstruksi pola-pola pewarisan yang tetap dan tidak meninggalkan pakem-pakem tradisi yang ada.
\end{abstract}

Kata kunci: revitalisasi, keris, gaya ngéntha-éntha 


\section{PENDAHULUAN}

Keris adalahsalah satu jenis senjata tradisional Jawa yang dibuat dari bahan besi yang berkualitas tinggi. Dua sisi bilahnya adalah tajam dan ujungnya runcing.Bagi orang Jawa, keris tidak hanya dianggap penting, tetapi juga diagungkan. Menurut Denys Lombard(2005: 194), di masa lalu orang kaya atau miskin di Jawa memiliki keris di rumah; tidak ada laki-laki yang berumur antara dua belas sampai delapan puluh tahun berani keluar rumah tanpa keris terselip disabuknya.Salah satu peran kerisadalah sebagai unsur seni budaya tradisi yang berfungsi untuk meningkatkan kehidupanseremonial pada semua peristiwa penting, baik di istana raja maupun di dalam komunitas desa (Holt, 2000: xxix). Pembuat keris mendapat sebutan empu. yaitu seorang pandhé (perekayasa) besi yang menunjukkan kualifikasi keahlian serta kedudukan di atas pandhé besi biasa (Soeratno, 2008: 228).Setiap keris memiliki ciri khas atau identitas yang disebut tangguh. Di Yogyakarta terdapat keris tangguhHamengku Buwana (HB) Yogyakarta yang lahir di lingkungan kerajaan dan keris tangguh ngéntha-éntha yang lahir di lingkungan komunitas Desa Ngéntha-Éntha, sebelah barat wilayah Godean, Kabupaten Sleman, Yogyakarta.

Jejak pembuatan keris tangguhngénthaéntha Yogyakarta di Desa Ngéntha-Éntha Yogyakarta memiliki cerita sejarah panjang. Hal itu, tercermin pada catatan silsilah para empunya yang termuat dalam buku Bab Dhuwung yang dimulai dari empu (maestro) pembuat keris terkenal zaman Kerajaan Majapahit, yaitu Empu Supodriyo (Darmosoegito, 1961: 46). Keahlian Supodriyo menurun kepada anak cucunya sampai pada keturunannya yang hidup di zaman Kerajaan Islam Mataram Kartasura. Salah satu keturunannya yang dikenal di zaman Kerajaan Islam Mataram Kartasura adalah Empu (Éntha) Wayang, sebagai empu yang menjadi cikal bakal Desa Ngéntha-Éntha. Dengan demikian pembuatan keris di Yogyakarta sudah mengakar sejak Kerajaan Islam Mataram Kartasura yang dimulai oleh Empu Wayang di Desa Ngéntha-Éntha tersebut (Soesmoro, 2010: 295).

Selanjutnya keahlian Empu Wayang menurun kepada anak cucu pewarisnya yaitu Empu Supowinangun, Empu Yosopangarso, Empu Jeno Harumbrojo, dan yang masih hidup saat ini yaitu Empu Sungkowo, yang sering juga disebut Empu Sungkowo Harumbrojo karena dia adalah cucu dan kemenakan Empu Jeno Harumbrojo. Meskipun begitu pewarisan keahlian ini tidaklah semulus yang diper-kirakan banyak orng karena sejak meninggalnya Empu Supowinangun tahun 1963, pembuatan keris di desa tersebut terputus sampai menjelang tahun 1975. Hal itu terjadi karena pengaruh berbagai faktor seperti belum siapnya pewarisannya, karena anak-anaknya seperti Yosopangarso dan adik-adiknya masih terbatas kemampuannya. Kondisi negara waktu itu juga sedang tidak menentu akibat terjadinya revolusi sosial, bentrokan antar golongan dan agama, serta kudeta tahun 1965-1966 yang menewaskan jutaan manusia (Guritno, 2006: 50). Situasi itu ikut menjadi faktor terputusnya kesinambungan pembuatankeris tangguh ngéntha-éntha di Desa Ngéntha-Éntha Yogyakarta, sehingga sampai menjelang tahun 1975 telah terjadi kekosongan profesi empu keris (Harsrinuksmo, 2008: 148). Kurun waktu terputusnya pembuatan keris di Desa Ngéntha-Éntha dapat berarti pembuatan keris di Jawa benar-benar sampai pada titik akhir (Mulder, 1984: 90). Akan tetapi, asumsi yang mengira bahwa pandangan 
dan tata kehidupan moral masyarakat Jawa sudah berubah total karena dinamika politik, sosial, ekonomi, budaya,dan pengalaman buruk masa lalu, ternyata tidak sepenuhnya benar. Desa-desa bekas pusat pembuatan keris di Jawajuga masih menyimpan potensi laten yang sewaktu-waktu dapat bangkit dan tumbuh lagi jika mendapat pengaruh positif dari luar (Guritno, 2006: 50). Tahun 1975 merupakan tahun bersejarah karena menjadi awal upaya pelestarian kembali penggarapan keris tangguh Ngéntha-Éntha di Yogyakarta. Upaya pelestarian kembali ini melibatkan tiga tokoh utama pembuat keris, yaitu Empu Yosopangarso, Empu Jeno Harumbrojo, dan Empu Sungkowo.

\section{METODE}

Metode yang digunakan dalam penelitian ini adalah metode sejarah yang kemudian dikaitkan dengan sejarah gaya. Tahap pertama dalam metode sejarah adalah menemukan dan mengumpulkan sumber sejarah yang relevan dengan pokok bahasan penelitian (heuristic). Tahap kedua adalah melakukan kritik terhadap sumber sejarah tersebut untuk mengetahui keotentikan dan kredibilitas sumber sejarah tersebut. Tahap ketiga adalah menganalisis secara objektif pokok bahasan penelitian berdasarkan hasil yang diperoleh pada tahap pertama dan kedua (Garraghan S.J., 1957: 3).

\section{HASIL DAN PEMBAHASAN}

\section{Awal Penggarapan Keris Tangguh Ngéntha- Éntha}

Awal penggarapan kerisTangguh Ngéntha-Entha diperkirakan sudah adajauh sebelum kerajaan Yogyakarta berdiri. Menurut Empu Sungkowo, selain di desa tersebut aktivitas penggarapan keris juga tumbuh diDesaBalangan, Cebongan, Sumberan, dan Jenggalan, namun entah bagaimana kemudian hilang begitu saja.
Sebaliknya yang berada di Desa NgénthaÉntha tumbuh menjadi tradisi penggarapan keris yang hidup, unik, dan menarik sampai sekarang. Menurut Supardi Prawirodipuro dalam Suwarsono Lumintu (2004: 16), tokoh empu keris yang menjadi pemulanyaadalah Empu Éntha Wayang.Ketokohan empu tersebut tercermin pula dalam cerita masyarakat setempat. Cerita itu masih kental, karena empu tersebut sekaligus juga dianggap sebagai nenek moyang mereka.

Sejarah keberadaan empu kerisdi Jawa menurut Hamzuri, tidak terpisahkan dengan keberadaan kerajaan. Mereka terkait karena biasanya menjadi bagian dari keluarga atau abdi dari suatu kerajaan tertentu. Dengan sendirinya keberadaan para empu keris sangat bergantung pada kekuasaan raja. Oleh karena itu pada masa lampau pusat penggarapan keris di Jawa sering berpindah-pindah tempat mengikuti jatuh bangunnya suatu kerajaan (Hamzuri, 1984: 1).Sementara itu kerajaan yang sedang tidak lagi mampu mencukupi kebutuhan hiduppara empu seringkali mendorong para empu keris tersebut berhenti atau berpindah tempat ke tempat atau daerah lain (Ranuwijaya, 2009: 39).

Pengaruh kekacauanyang terjadi pada kekuasaan Kartasuraseperti munculnya intrik keluarga dan pemberontakan yang tidak kunjung selesai, telah menghasilkan situasi anarki kerajaan selama 60 tahun (Ricklefs, 2002: 2005).Raja yang berkuasa tidak lagimampu menopang kehidupanpara empu, termasuk Empu Wayang.Empu Wayang misalnyadiduga telah menyingkir dari lingkungan istana dan memasuki sebuah desa di dekat Godean, Yogyakarta, yang kemudian dinamakanDesa NgénthaÉntha, mengikuti namanya yaitu Empu (Éntha) Wayang.

Setelah terjadinya perjanjian Giyanti, maka pandangan keraton terhadap 
keberadaan garapan keris Jawa berubah, baik di keraton Kasunanan Surakarta maupun Kasultanan Yogyakarta. Di kedua kerajaan tersebut, pengggarapan keris sudah tidak lagi menjadi monopoli para empu istana. Penggarapan keris sudahtumbuh sampai pelosok-pelosok desa dan sudah menjadi pekerjaan sebagaian warga masyarakat seperti di Desa Ngéntha-Éntha Yogyakarta. Walaupun demikian tidak semua orang kemudian membuat keris, karena masyarakat percaya bahwa penggarapan keris bukanlah jenis pekerjaan fisik saja, namun juga pekerjaan batin sang empu (Hamzuri, 1984: 14).Hal itu menunjukkan, bahwa penggarapan keris di Desa NgénthaÉntha Yogyakarta memang sudah ada sejak sebelum lahirnya Kerajaan Yogyakarta, karena pada waktu itu penggarapan keris sudah menjadi pekerjaan masyarakat, untuk menjadi pekerjaan masyarakat tentu sudah dimulai jauh sebelumnya.

Pengaruh budaya penggarapan keris kraton terhadap budaya penggarapan kerisDesa Ngéntha-Éntha tampaknya juga kuat.Secara umum menurut Kuntowijoyo, karena sarana produksi dikuasai oleh pusat kerajaan, maka dominasi kebudayaan kraton memancarkan sinarnya ke kebudayaan desa, sehingga penyebaran kebudayaan tinggi terjadi di lingkungan budaya rakyat (Kuntowijoyo, 2006: 31). Oleh karena itu, secara spesifik keris desa khususnya hasil garap keris dari Desa Ngéntha-Éntha Yogyakarta juga mendapat cerminan nilai budaya tinggi, terbukti para empu desa tersebut juga sering dipercaya melayani keris untuk kalangan keraton. Pengaruh nilai itu merasuk dalam garap keris di luar keraton, muncullah warna dalam hasil garapan yang berbeda, karena menyesuaikan rambu-rambu yang boleh atau yang tidak boleh sama dengan garap keris keraton.
Keberadaan Empu Wayang, selain dikenal sebagai tokoh pendiri desa, juga tokoh peletak tonggak sejarah awal adanya garap keris tangguhngéntha-éntha Yogyakarta dan ke-pandhé-an pada umumnya di Desa Ngéntha-Éntha. Kepiawaian dan bakat keempuan Empu Wayang terpancarkan melalui seni olahan besi tempanya pada lingkungan masyarakat sedesanya. Pengaruh kuat individunya itu memunculkan profesi masyarakat sedesa yang berorientasi di bidang yang sama, yaitu perkerisan atau paling tidak profesi yang terkait dengan penggarapan besi.

Generasi empu keris, baik dari unsur masyarakatseperti pada masa Empu Tarunadahana, maupun dari unsur keturunan seperti keturunan Empu Wayang sendiri yaitu Empu Badur, Empu Supowinangun, dan seterusnya tumbuh mengikuti jalan tradisi. Menurut Umar Kayam(1981: 97), tradisi tidak pernah tertempa dalam waktu yang pendek, ia membutuhkan suasana yang lama untuk membiarkan kebiasaan berjalan matang menjadi tradisi.Terkait itu, tampaknya tradisi pertumbuhan keris tangguhngénthaéntha Yogyakartapun memasuki pertumbuhan tradisinya dalam tempo yang lama untuk menuju kematangannya.

Bentuk, cara penggarapan, dan alat-alat yang digunakan pantang keluar dari kebiasaan lama, baik karena unsur keturunanya seperti Empu Badur dan seterusnya maupun empu warga-wargapengikutnya. Generasi setelah Empu Badur adalah Empu Kartayuda, anak Empu Badur. Menurut Empu Sungkowo, Empu Badur maupun anaknya masing-masing diduga telah membuat tiruan/mutrani keris dengan gaya Empu Wayang yang telah luluh menjadi gaya Desa Ngéntha-Éntha.

Empu Kartayuda menurunkan anak bernama Djoirana. Anak tersebut yang 
meneruskan keahlian ayahnya dan selanjutnya menjadi dikenal sebagai Empu Djoirana.Empu Djoirana sebagai empu keris juga menurunkan keahliannya kepada putranya bernama Supowinangun yang kemudian lebih terkenaldengan dengan sebutan Empu Supowinangun. Empu Supowinangun termasuk salah satu di antara empu-empu di Desa Ngéntha-Éntha yang garapan kerisnya terkenal bagus.

Dalam perjalanan sejarahnya, penggarapan keris di Desa Ngéntha-Éntha pernah mengalami kelangkaan bahan pamor dan kondisi ini sebenarnya sudah terjadi sejak Empu Supowinangun aktif berkarya di zaman sebelum Indonesia Merdeka. Saat itu, keris-keris buatannya lebih banyak berpamor nikel, karena bahan pamor meteor sudah sangat sulit didapatkan. Empu Supowinangun adalah empu terakhir menjelang Indonesia merdeka. Ia menggarap keris dengan pamor meteor hanya jika mendapat pesanan dari keraton Yogyakarta yang bahan pamornya disediakan oleh pihak keraton (Harsrinuksmo, 2008: 452). Ketika Jepang menjajah Indonesia, bahan baku keris semakin langka karena banyak dibutuhkan bagi industri penunjang peralatan perang. Pada waktu itu ada juga larangan untuk membuat, menyimpan, dan memperjualbelikan senjata oleh bala tentara pendudukan Jepang termasuk keris.

Kelangkaan bahan-bahan terutama bahan pamor telah memperburuk harapan kelangsungan penggarapan keris, di Desa Ngéntha-Éntha khususnya. UmurEmpu Supowinangun tahun 1960-an sudah memasuki usia tua, sehingga tenaganya sudah berkurang untuk mengangkat palu tempanya.Satu-satunya besalèn(dapur tempa) keris di Desa Ngéntha-Éntha milik Empu Supowinangun akhirnya tidak dapat dipertahankan dan surut dari segala aktivitasnya. Riwayat sejarahnya kemudian benar-benarterputus setelah Empu Supowinangun meninggal dunia tahun 1963.

\section{Kebangkitan Kembali Keris Tangguh Ngéntha-Éntha}

Pada tahun 1973, seorang peneliti budaya keris Jawa asal Hawaii, Amerika Serikat, bernama Garrett Solyom mengunjungi Desa Ngéntha-Éntha Yogyakarta menemui Yosopangarso. Pertemuannya dengan Yosopangarso telah mendorong minat Solyom terhadap budaya penggarapan keris yang semakin mantap, sehingga pada tahun 1976-1977 ia datang lagi ke kediaman Yosopangarso. Kedatangan Solyom itu atas sponsor Museum Radyapustaka Surakarta untuk mendokumentasikan proses pembuatan keris di Yogyakarta yang akan dikerjakan oleh Yosopangarso dan Jeno Harumbrojo, adiknya. Ketika Jeno Harumbrojo berkeinginan untuk membangun sendiri besalén penempaan logam di desa Gatak, dekat dengan besalén awal (lama), Solyom mencari dukungan keuangannyadari Ford Foundation Traditional Arts Committee di Jakarta. Hal itu menurut Solyom, memungkinkan Jeno Harumbrojo memulai karirnya yang tranformatif sebagai seorang empu. Dengan kata lain, kedatangan Solyom, selain terkait dengan penelitiannya tentang budaya keris Jawa, sekaligus memberikan dorongan dan uluran tangan kepada Yoyopangarso dan Jeno Harumbrojo, melalui usahanya lewat yayasan tersebut. Kedatangan Solyom bagi Yosopangarso dan Harumbrojo bukan sekedar tamu biasa, karenakeperdulian Solyom telah memberi arti tersendiri yang memicutekadnya, sehingga metode penggarapan keris tradisi mulai dapat dilacak dan diangkat kembali didalam suasana era baru (Wawancara dengan Empu Sungkowo). 
Revitalisasi keris tangguh ngénthaénthajuga tidak bisa dilepaskan dari peran Dietrick Drescher, seorang kapten kapal dan pengagum keris berkebangsaan Jerman. Pada tahun 1975 ia datang ke Yogyakarta dengan tujuan utama ke Desa Ngéntha-Éntha. Kedatangan Drescher ke desa tersebut untuk menemui Yosopangarso, anak pertama almarhum Empu Supowinangun,meminta untuk dibuatkan keris pusaka. Permintaan ini jelas tidak mudah dipenuhi karena Yosopangarsodan Jeno Harumbrojo, adiknya, dulu belum sempat belajarmembuat keris secara serius dari ayahnya, yaitu Empu Supowinangun, karena sang ayah keburu meninggal dunia. Oleh karena itu, permintaan Drescher itu tidak langsung mereka penuhi karena bekal ilmu perkerisan yang mereka miliki hanya sedikit.

Drescher mengerti kalau mereka belum sepenuhnya siap untuk memenuhi permintaannya, namun Drescher terus memberikan perhatian dan dorongan. Ia juga memberikan modal kerja untuk re-kreasi pembuatan keris tangguh lama kepada Yosopangarso bersaudara. Dalam konteks upaya pelestarian budaya tradisional, inisiatif Drescher ini merupakan sebuah ironi, mengapa justru orang asing yang peduli terhadap kebangkitan keris Jawa, keristangguhngéntha-éntha Yogyakarta khususnya.Drescher hadir pada saat yang tepat,pada waktubenih keahlian keempuan belumhilang dari benak Yosopangarso dan Jeno Harumbrojo, sehingga re-kreasinya tidak terlalu lama dapat berhasil melahirkan karya seni keris baru.

Kontribusi Drescher, selain mengantar Yosopangarso dan JenoHarumbrojo menjadi empu keris profesional masa kini, juga menyambung terputusnya sejarahempu keris tangguhngéntha-éntha Yogyakarta. Peristiwa itu oleh masyarakat perkerisan dianggap menjadi tonggak sejarah baru pertumbuhan keris Indonesia. Terbukti bekas pusat keris di daerah-daerah lain di Indonesia terinspirasi kebangkitan keris tangguhngéntha-éntha Yogyakarta tersebut, sehingga Drescher diakui oleh kalangan perkerisan sebagai orang yang berjasa menghidupkan kembali perkerisan di Indonesia(Harsrinuksmo, 2008: 148).

Dukungan dari luar dan dalam negeri semakin kuat karena Panembahan Harjonagoro alias Go Tik Swan juga berperan mengarahkan dan mendanai proyek keris Empu Jeno Harumbojo, demikian juga dukungandari penggiat perkerisan Haryono Haryo Guritno.Dukungan yang terus mengalir membuat Empu Yosopangarso dan adik-adiknya melewati masa-masa sulit. Dengan demikian penggarapankeris tangguh ngéntha-éntha Yogyakarta telah mendapat energi positif bagi eksistensi sejarah hidupnya. Dukungan yang diberikan oleh mereka juga tidak hanya menyangkut aspekpengembangan bentuk, tetapi juga aspek popularisasi keris tangguh ngéntha-énthaYogyakartadi tingkat lokal, nasional, maupun internasional.

Kebangkitan para empu di Desa Ngéntha-Éntha Yogyakarta memberi makna bagi generasi kini tidak sampai kehilanganalur ( $\mathrm{Jw}=$ ora kepaten obor $)$ tradisi budayanya sendiri yang diyakini masih dapat bermanfaat pada masa kini dan mendatang. Akan tetapi, kebangkitan itu teruji kembali dengan meninggalnya salah satu tokohnya yaitu Empu Yosopangarso pada tahun 1979, kemudian disusul kedua adiknya yang kurang begitu terkenalyaitu Genyodiharjo dan Wignyosukoyo (Harsrinuksmo, 2008:540). Akibat peristiwa itu, maka estafet keempuan tangguhngénthaéntha Yogyakarta beradadi pundak Empu Jeno Harumbrojo, anak bungsu Empu Supowinangun. 
Empu Jeno Harumbrojo kemudian memacu niatnya untuk menggali potensi talentanya yang dulu belum sepenuhnya teraktualisasikan bersama kakak-kakaknya. Di besalèn yang ia bangun di dekat rumah tinggalnyadi Desa Gatak, sebelah barat Desa Ngéntha-Éntha, dia mulai memfokuskan diri untuk pembuatan karya-karya pribadinya. Dengan cara itu, ia mematangkan keahliannya dan mengabdi penuh pada profesinya.

Konsep dasar karya Empu Jeno Harumbrojo berlandaskan pada kematangan jiwa pribadi dan laku tradisi yang dijalankan secara ketat selama proses berlangsung. Landasankonsep berkarya yang sedemikian itu menurut para pemerhati budaya keris, sudah tidak mudah ditemukan di tempat lain, bahkan kemungkinan sudah tidak ada lagidi Indonesia. Oleh karena itu, nama Harumbrojo kemudian dikenal sebagai satu-satunya empu keris legendaris dari Yogyakarta yang mampu membuat keris secara tradisi penuh (Neka, 2009: 6).

Masa hidup Empu Jeno Harumbrojo dihabiskan untuk memelopori dan menekunitradisi pembuatan keris tradisional di zaman Indonesia merdeka. Ia berperan memberikan harapan baru bagi citra keris Indonesia di mancanegara.Terbukti, Tahun 2005 Perserikatan Bangsa Bangsa (PBB), melalui lembaga kebudayaannya TheUnited Nations Educational, Scientific and Cultural Organitation (UNESCO), menetapkan keris Indonesia tercatat dalam daftar representatif benda budaya warisan manusia (Mancacaritadipura, 2009: 4). Penetapan itu menunjukkan reputasi keris Indonesia yang tidak tertandingidi dunia. Pelestari tradisi sekaligus pembuat keris paling berpengaruhnyapun masih ada, yaitu Empu Jeno Harumbrojo dan kini dilanjutkan oleh Empu Sungkowo.
Sepeninggal Empu Jeno Harumbrojo pada tahun 2006, penerus pembuatan keris tangguh ngéntha-éntha Yogyakarta berada ditangan Empu Sungkowo yang dikenal juga dengan nama Empu Sungkowo, anak angkat sekaligus kemenakan Jeno Harumbrojo. Empu Sungkowo, telah lama dipersiapkan sebagai penerus Empu Jeno Harumbrojo sebelum yang disebut belakangan ini meninggal dunia. Empu Sungkowopun mengikuti jejak kepiawaian mendiang ayah angkatnya yang konsisten berkarya mengikuti tradisi.

Hingga sekarang keris, termasuk karya Empu Sungkowo, masih dicari orang bukan hanya karena semakin langka, tetapi karena masih berperan secara sosial (Rudyansah, 2009: 9). Pada era reformasi pembuatan keris di besalèn Empu Sungkowo masih tetap menjadi daya tarik masyarakat. Orang datang, baik dari dalam maupun luar negeri dengan membawa berbagai kepentingan. Ada yang sekedar mengagumi, memesan, studi, atau meliputnya sebagai dokumen.

Perjuangan panjang para empu keris tangguh ngéntha-éntha Yogyakarta kinitelah memasuki dasa warsa ke empat sejak awal kebangkitannya tahun 1975. Mereka telah diapresiasi oleh berbagai kalangan, termasuk pemerintah pusat yang menganugerahkan 'Tanda Kehormatan Bintang Budaya Parama Dharma'kepada Empu Jeno Harumbrojo yang telah berjasa besar terhadap bangsa dan negara dalam meningkatkan, memajukan, dan membina kebudayaan nasional. Tanda kehormatan tersebut disampaikan langsung oleh Presiden Megawati Soekarno Putri, di Istana Negara tahun 2003 silam dalam acara peringatan Hari Ulang Tahun Ke-58 Kemerdekaan Republik Indonesia. Hal itu, memberikan bukti bahwa ia telah berjasa 
kepada bangsa dan Negara, kemudian dapat memberi motivasi dan teladan kepada generasi masa mendatang.

Usaha keras para empu anak-anak mendiang Empu Supowinangun untuk mendapatkan apresiasi masyarakat juga dilakukan dengan cara melalukan pameran-pameran keris karya-karya mereka. Pada tahun 1977, seperti terlihat dalam buku catatan kegiatan pribadi Empu Jeno Harumbrojo, upaya mendapatkan dukungan dan apresiasi masyarakat terhadap garapankeris baru buatan empu-empu dari Desa Ngéntha-éntha dilakukan dengan cara mengikuti pameran di kelurahannya sendiri, yaitu di Kalurahan Sumberagung.

Upaya berikutnya mereka mengikuti pameran di luar desa mereka dan dilakukan pada tahun 1978 di Sekolah Menengah Pertama Godean, di Hotel Ambarukmo, dan di Kabupaten Sleman. Tahun 1980 mereka mengikuti pameran seni di Gedung Purnabudaya Bulaksumur Yogyakarta. Tahun 1981, tiga bilah keris karya Empu Jeno Harumbrojo dipinjam oleh panitia pameran di Purnabudaya, Bulaksumur, Yogyakarta untuk dipamerkan ditempat tersebut.

Tahun 1982,mereka kembali menyelenggaran pameran didesanya danpada tahun 1984 mereka mulai mengikuti pameran di Sitihinggil Keraton Yogyakarta, hampir satu bulan lamanya. Pameran di Sitihinggil Keraton Yogyakarta selanjutnya diikuti hampir setiap tahun yaitu tahun 1985, 1986, 1987, 1989, 1990, 1991, 1992, 1993, 1994, 1996, 1997, 1999, 2000, dan seterusnya sampai sekarang.

Tahun 1990, selain mengikuti pameran di keraton Yogyakarta, mereka juga mengikuti pameran bersama dengan Institut Seni Indonesia Yogyakarta di Hotel Ambarukmo Yogyakarta. Tahun 1991, mereka mengikuti pameran di Puro Pakualaman Yogyakarta dalam rangka Tahun Kunjungan Indonesia di Yogyakarta. Keikutsertaan pada pameran-pameran tersebut dengan sendirinya mengakibatkan hasil garapan keris dari Desa Ngéntha-Éntha semakin dikenal masyarakat secara luas dan membuktikan, bahwa penggarapan keris dari desa tersebut tumbuh kembali.

Tahun 1977, garapan keris Desa Ngéntha-Éntha selain dapat tampil pada acara pameran-pameran juga sudah mulai menjadi perhatian awak media. Di dalam catatan Empu Jeno Harumbrojo garapan keris Desa Ngéntha-Éntha sudah tampil di beberapa surat kabar nasional seperti Sinar Harapan, Tempo, dan Berita Buana.Tema yang diangkat seputar kegiatan keempuan Yosopangarso dan Harumbrojo. Tahun 1979, majalah Ambassador juga memuat kegiatan empu keris Desa Ngéntha-Éntha. Tahun-tahun berikutnya aktivitasnya juga dimuat oleh harian Kadaulatan Rakyat dan Buana Minggu. Hal itu menunjukkan bahwa kehadiran garapankeris baru corak tradisi masih dan mulai mendapat perhatian. Garapan keris tersebut masih mendapat tempat bagi kelanjutannya, meskipun wilayah Jawa terus terselimuti arus budaya modern.

Pada tahun 1978,besalènpenggarapan keris Empu Jeno Harumbrojo dipercaya oleh pemerintah untuk menyelenggarakan kursus praktik membuat keris bagi warga Desa Ngéntha-Éntha dan sekitarnya. Mereka yang dahulu pernah berprofesi sebagai pandhé besi diikutkan menjadi pesertanya. Kursus itu diselenggarakan sebagai upaya mencari bibit empu baru yang nyaris punah. Kursus tersebut disponsori dan dibiayai olehBadan Penelitian Logam Dasar. Jumlah peserta mencapai tiga puluh orang mantan pandhépacul, sabit, bendo, dan lain-lain dari Desa NgénthaÉntha, Jenggalan, Nulisan, Sumberan, 
Gedongan, dan Dongkelan. Mereka diberi materi pengetahuan perkerisan dan praktik langsung membuat keris. Empu Yosopangarso menjadi gurunya dan Empu Jeno Harumbrojo menjadi asistennya selama lima bulan kursus tersebut diselenggarakan.

Rentang waktu penyelenggaraan kursus itu di dalam cacatan pribadi Empu Jeno Harumbrojo adalah dari tanggal 10 Juni 1978 sampai dengan tanggal 15 Oktober 1978. Kursus dilaksanakan pada setiap hari Minggu agar pekerjaan seharihari dari peserta tidak terganggu. Akan tetapi, pada akhir masa kursus disadari tidak adanya hasil seperti yang diharapkan karena faktor terbatasnya dana penyelenggaraan. Oleh karena itu,kursus tersebut tidak dilanjutkan pada tahap berikutnya, sehingga belum didapatkan kader empu desa yang baru selain keturunan Empu Supowinangun. Tinggallah Empu Yosopangarso dan Empu Jeno Harumbrojo, adiknya, yang tetap menggeluti profesi menjadi empu keris.

Seiring dengan bertambahnya pengalaman, maka Empu Yosopangarso dan Empu Jeno Harumbrojo, semakin profesional. Kepakaran mereka sulit dicari bandingannya, sehingga semakin dibutuhkan masyarakat luas. Pada tanggal 1 sampai dengan 20 Desember 1978 mereka dipercaya mengawali penggarapan keris di besalèn Anjungan Mataram Daerah Istimewa Yogyakarta, Taman Mini Indonesia Indah, Jakarta. Hal itu menunjukkan bahwa pengggarapan keris masih ada dan masih diperlukan di tingkat yang lebih luas.

Empu Jeno Harumbrojo menyelesaikan penggarapan keris di besalèn Anjungan Mataram Daerah Istimewa Yogyakarta, Taman Mini Indonesia Indah, tahun 1979. Setelah itu ia dipercaya memberikan materi kursus pembuatan keris Jawa di Imogiri Yogyakarta. Kursus diikuti oleh tiga puluh orang peserta, selama sepuluh hari kerja. Meskipun dana terbatas dan waktukursus yang tersedia sangat singkat, namun cukup memberi bekal kepada para peserta. Hal itu tercermin pada kegiatan penduduk desa Imogiri yang sebagian besar bergelut pada produk dan jasa yang berhubungan dengan perkerisan.Contohnya adalahseperti jasa reparasi bilah keris, pusat pembuatan produk sarung keris, maupun pembuatan aksesorisnya.

Sebagian mantan peserta kursus kemudian menjalin kerjasama simbiosis mutualisme mencukupi kebutuhan sarung keris bagi empu di Desa Ngéntha-Éntha sampai sekarang. Oleh karena itu, perhatian masyarakat perkerisanpun semakin tertuju kepada Empu Yosopangarso dan Empu Jeno Harumbrojo. Bahkan beberapa

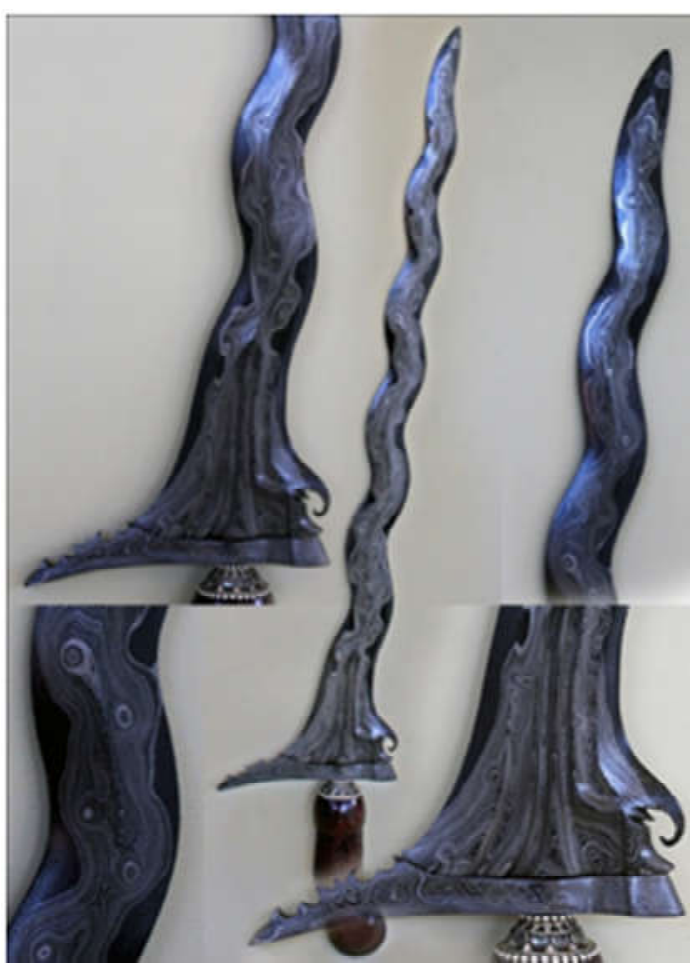

Gambar 1.

Keris luk 11, dhapur Sabuk Inten, pamor Beras Wutah karya Empu Jeno Harumbrojo (foto oleh Nizam 2012). 
instansi tertarik melakukan shooting film pembuatan keris di besalen mereka.Pihak Museum Sono Budoyo Yogyakarta juga tidak ketinggalan pernah merekam kegiatan proses penggarapan keris Empu Yosopangarso dan Empu Jeno Harumbrojo di Desa Ngéntha-Éntha. Selain dari museum, menurut catatan Empu Jeno Harumbrojo, dokumentasi juga dilakukan lewat shooting film oleh sebuah stasiun televisi dari negara Belanda atas kerjasama dengan Institut Teknologi Bandung. Hasilshootingitu kemudian disebarluaskan ke 13 negara di Eropa. Dampaknya sangat dirasakan oleh Empu Jeno Harumbrojo sehingga iamerasa semakin dikenal dan kemudian banyak dikunjungi tamu dari luar negeri. Hal ini memang masuk akal karena keris ciptaannya memang sangat bagus (Gambar 1).

Tahun 1980 perekaman proses keris juga dilakukan oleh Departemen Pendidikan dan kebudayaan Republik Indonesia. Tahun 1987 ada perekaman yang dilakukan oleh stasiun TVRI Yogyakarta untuk acara profil budaya. Semenjak ditayangkan di televisi, baik di dalam maupun di luar negeri, dampaknya bagi Empu Jeno Harumbojo terus positif. Ia kemudian sering diminta menjadi narasumber dalam sarasehan atau seminar yang bertemakan keris. Tahun 1984, ia pertama kali tampil sebagai penceramah di proyek Javanologi Museum Sono Budoyo Yogyakarta dengan tema 'Keris Bertuah'. Di samping itu, mulai semester gasal tahun 1994 Empu Jeno Harumbojo dipercaya menjadi dosen luar biasa mata kuliah Tosan Aji di Institut Seni Indonesia (ISI) Yogyakarta. Sebetulnyamata kuliah tersebut sudah diberikan di institut seni tersebut sebelum tahun itu, tetapi masih bersifat informal.
Empu Jeno Harumbrojo konsiten dengan penggarapan keris secara tradisional dan tampaknya konsistensi itu telah mengangkat reputasinya semakin tinggi. Sejumlah karya dihasilkan Empu Jeno Harumbrojo sejak ditinggal Empu Yosopangarso dari tahun 1990 sampai dengan tahun 2005.Menurut catatan pribadinya, ia telah membuat keris lebih dari seratus bilah.Tentu hal itu merupakan sebuah prestasi kesenirupaan yang tergolong gemilang, karena dibanding sebelum tahun 1990 ia hanya mampu menggarap keris sekitar 37 bilah. Jadi ada peningkatan kuantitas yang cukup siknifikan disamping kualitas selama kurang lebih 15 tahun terakhir itu.

Empu Jeno Harumbrojo usianya sudah tua, namun tetap menjadi perhatian media.Tahun 1992 dilakukanshooting film terhadap proses pembuatan keris Empu JenoHarumbrojo oleh PT. Avigra yang bekerjasama dengan BDNI, disusul shooting dari Prancis dan SCTV, dan tahun 1994shooting dari Kanada. Kegiatan sang empupun semakin padat.Menjelang akhir hidupnya tahun 2005 ia masih sempat diwawancarai oleh reporter untuk siaran radio. Kolektor keris punsudah mulai memburu keris karya Empu Jeno Harumbrojo.Setelah meninggalnya tahun 2006 karya-karyanya terus diburu para kolektor keris.

\section{Masa Depan Pelestarian Keris Tangguh Ngéntha-Éntha}

Generasi empu keristangguh ngénthaéntha Yogyakartasekarang adalahEmpu Sungkowo atau Empu Sungkowo Harumbrojo. Ia bertempat tinggal di bekas rumah dan bekerja di besalèn mendiang Empu Jeno Harumbrojo, ayah angkatnya. Lokasinya di desa Gatak sebelah barat Desa 
Ngéntha-Éntha. Empu Sungkowo adalah generasi penerus empu keris tangguh ngéntha-éntha Yogyakarta. Ia tampak tetap setia menunjukkan kepiawaiannya dengan caranguri-uri tradisi keempuan nenek moyangnya. Doa, sesaji, dan puasa selama 40 hari menurut hitungan Jawa, yaitu hari Rabu Pon, Kamis Wage, dan Jum'at Kliwon tetap dijalankan scara ketat saatproses pembuatan keris berlangsung. Pada saatnya pulaproses penggarapan keris tidak dilakukan pada hari Selasa Pahing, Rabu Wagé, Kamis Pahing, Kamis Wagé, dan Kamis Legi, karena dianggap hari naas. Empu Sungkowo tidak mau melanggar pantangan hari tersebut. Menurut Empu Sungkowo,hari-hari naas atau hari pantangan kerja dibesalèn jika diterjang dapat memberi pengaruh negatif, contohnya membakar besi saja tidak dapat menjadi merah [panas] (Anshori, 2009: 16).

Empu Sungkowo mengaku belajar membuat keris sejak masih di bangku Sekolah Dasar, saat itu iabiasaikut bekerja membantu orang tuanya di besalèn. Ia mengambil peran seperti menempa besi, memotong calon ganja, dan sebagainya. Empu Jeno Harumbojo membimbing secara langsung anak angkatnya tersebut.Hal itu menunjukan, bahwaEmpu Sungkowo memang sudah dipersiapkan menjadi empu yang kelak menggantikannya. Terbukti menurut cacatan Empu Jeno Harumbojo, ia mulai dipercaya aktif sebagai pandhé sejak tahun 1997. Sejak tahun itu pula, ia sudah mulai menggarap karya pribadinya.Dengan demikian, maka setelah meninggalnya Empu Harumbrojo tahun 2006, Empu Sungkowo sudah tidak mengalami kesulitan dalam meneruskan pekerjaan penggarapan keris. Sekarang, Empu Sungkowo telah sepenuhnya menjadi empu keris yang tidak hanya menguasai teknik fisik saja, namun juga peng- hayatan batin dan laku tradisi yang biasanya menyertainya.

Ditangan Empu Sungkowo keris tangguh ngéntha-éntha Yogyakarta sekarang eksis dan tetap masih dikerjakan secara tradisional penuh (Gambar 1). Meskipun bukan perkara yang mudah memegang teguh tradisi yang telah diwariskan oleh leluhurnya, namun ia berusaha konsisten mempertahankan tradisi itu. Terkadang ia harus melawan zaman dan menghadapi tantangan yang semakin berat seperti banyaknya tawaran modal maupun peralatan modern yang digratiskan untuk mengembangkan produktivitasnya. Empu Sungkowo sebagai orang yang mempunyai predikat empu dengan tujuan berkarya untuknguri-uri tradisi tentu saja tetap menjalankan proses penggarapan keris secara tradisi semestinya sehingga tidak memerlukan alat-alat mesin sekalipun gratis.

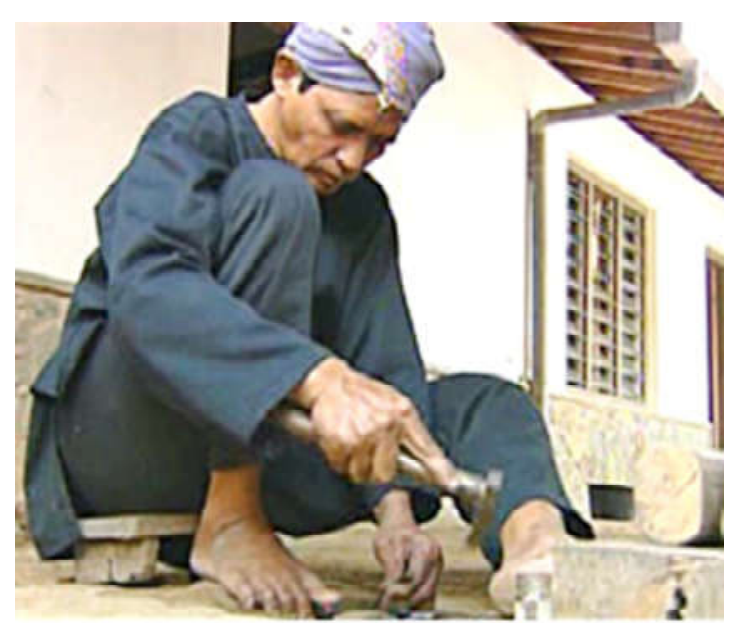

Gambar 2.

Empu Sungkowo sedang memahat bilah keris sesuai teknik rasa alat (foto oleh Nizam 2012). 
Empu Sungkowo sejak kecil memiliki nama lengkap Sungkowo, namun setelah Empu Jeno Harumbrojo meninggal, maka nama Harumbrojo sering dipakai di belakang nama Sungkowo, sehingga lengkapnya Empu Sungkowo Harumbrojo. Hal semacam itu dalam istilah Jawa dinamakan nunggak semi atau bernama sama dengan nama orang tuanya. Mengapa Empu Sungkowo sering menambah nama belakang Harumbojo, tentu merupakan suatu pilihan yang tidak sekedar lebih bagi popularitasnya, namun tentu terkandung makna yang terintegrasi dengan jiwanya untuk menghargai ayah angkat yang sekaligus merangkap gurunya.

Empu Sungkowo sekarang banyak dicari dan dibutuhkan masyarakat sebagaimana Empu Jeno Harumbrojo ketika hidupnya dulu sebagai empu yang mudah berinteraksi dengan segala lapisan. Hal itu tampak dengan adanya tamu yang datang silih berganti di rumahnya. Mereka datang dengan berbagai kepentingan: studi, wawancara, memesan keris, dan bahkan ada yang meminta pengobatan, tetap masing-masing terlayani dengan sepenuh hati. Hal itu ditunjanggaya penampilan Empu Sungkowo yang bersahaja dan ramah menyertai orang lain. Dia tidak ragumenemui tamu-tamunya, meskipun sekedar berbincang-bincang saja.

Kerja keras Empu Sungkowo telah menghasilkan beberapa bilah keris yang bagus (Gambar 3), baik yang sifatnya meneruskan penggarapan karya Empu Jeno Harumbrojo yang belum selesai, maupun pekerjaan pesanan dari luar. Pekerjaan Empu Sungkowo yang sifatnya pesanan sudah mengantri, sehingga peme san harus bersikap sabar menunggu pekerjaan itu dikerjakan sesuai antrian.

Tahun 2011 pesanan keris datang dari berbagai kalangan, seperti dari kerabat
Keraton Yogyakarta dan dari Sri Sultan Hamengku Buwana X. Di samping itu pesanan juga datang dari Duta Besar Slovakia. Pada tahun 2012 yang lalu pesanan yang mengantri juga berasal dari negara-negara lain, antara lainsatu bilah keris dari Belanda, dua bilah keris dari Singapura, satu bilah keris dari Jerman. Ini belum memperhitungkan antrian pesanan yang berasal dari dalam negeri. Antrian tersebut menurut Empu Sungkowo membutuhkan waktu tunggu sampai satu tahun, itupun tidak dapat dipastikan selesainya kapan.Sesuatu hal tertentu yang penting dapat saja menghentikan terlebih dahulu prosesnya untuk beberapa saat, kemudian baru dilanjutkan setelah keadaan memungkinkan kembali.

Saat ini, usia Empu Sungkowo sudah mencapai 60 tahun dan dalam menjalankan pekerjaannya dibantu oleh dua orang panjak (pembantu) yaitu Supardi dan Tugino.

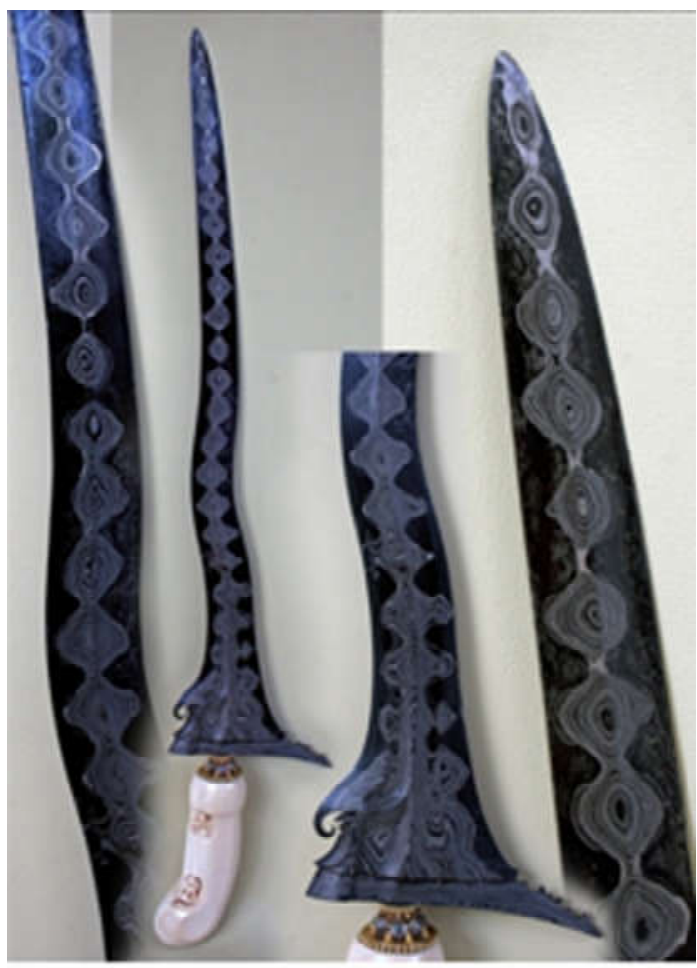

Gambar 3

Keris luk 3, dhapur Jangkung, pamor Bonang Sa'renteng, karya Empu Sungkowo (foto oleh Nizam 2012). 
Kedua panjak tersebut sudah ikut melayani kerja empu sejak mendiang Empu Jeno Harumbrojo, ayahnya, mulai kerja kembali di besalèn tahun 1975-an. Pekerjaan tersebut telah menjadi bagian dari hidupnya yang secara profesional dilanjutkan sampai sekarang. Mereka sudah sangat paham dan terampil membantu Empu Sungkowo. Mereka mengetahui bagaimana urutan kerja yang biasa dilakukanoleh Empu Jeno Harumbrojo maupun Empu Sungkowo. Akan tetapi, mengingat usia Empu Sungkowo dan usia merekasudah tua, namun ternyata empu penerus Empu Sungkowo belum dipersiapkan, hal ini tentu menimbulkan kekhawatiran janganjangan akan terjadi lagi kekosongan empu keris kelak seperti masa 1963 sampai menjelang tahun 1975. Hal ini tentu sangat mengancam revitalisasi yang telah berhasil dilakukan selama ini.

\section{SIMPULAN}

Tahun 1975 merupakan tahun emas bagi upaya revitalisasi keris tangguh ngéntha-éntha Yogyakarta yang sejak kematian Empu Supowinangun tahun 1963 telah berada di ambang kepunahan karena tidak ada lagi empu yang meneruskan pekerjaannya. Empu Yosopangarso dan Empu Jeno Harumbrojo, dua anak Empu Supowinangun yang masih remaja ketika ayahnya meninggal dunia, menjadi dua orang empu yang berhasil merevitalisasi penggarapan keris tangguh ngéntha-éntha Yogyakarta. Keris-keris yang mereka ciptakan sangat berkualitas sehingga memperoleh penghargaan nasional dan internasional.

Keberhasilan revitalisasi pembuatan keris tangguh ngéntha-éntha Yogyakarta di tempat aslinya yang telah dilakukan selama ini merupakan sebuah keistimewaan, sesuatu yang langka di bumi Indonesia yang sedang dilanda oleh modernisasi di semua bidang kehidupan. Harapannya adalah agar ciri khas gaya dan mutu garapan keris ini tetap dipertahankan.

\section{Catatan Akhir}

${ }^{1}$ Wawancara dengan Empu Sungkowo, tanggal 4 Nopember 2012.

${ }^{2}$ Wawancara dengan Empu Sungkowo tanggal 2-2-2012.

${ }^{3}$ Keseriusan Empu Jeno Harumbrojo melatih Sungkowo menempa keris jelas dipengaruhi oleh kepahitan masa lalu di mana ketika ayahnya Empu Supowinangun meninggal tahun 1963, dia dan kakanya Empu Yosopangarso merasa masih belum mewarisi ilmu penggarapan keris yang dimiliki oleh ayahnya. Hanya karena dorongan Garrett Solyom, Dietrick Deschler, KRT Harjonegoro (GO Tik Swan), dan lain-lain barulah keduanya bersedia menggarap keris. Hal itupun dilakukan agak dengan berat hati bukan hanya karena mereka merasa belum mewarisi ilmu penggarapan keris milik ayahnya, tetapi juga karena secara mental mereka berdua belum siap. Hal ini disebabkan karena menggarap keris juga harus disertai dengan ritual yang tidak mudah.

${ }^{4}$ Dari segi penguasaan ilmu penggarapan keris mungkin Supardi dan Tugino sudah memadai, artinya siap diangkat menjadi empu. Persoalannya tidak semudah itu karena penetapan seseorang menjadi empu juga berdasarkan penilaian masyarakat. Hal ini menjadi dilema dari sisi regenerasi karena Supardi dan Tugino sudah tua.

\section{Daftar Pustaka}

Bambang Harsrinuksmo

2008 Ensiklopedi Keris,Jakarta: Gramedia Pustaka Utama.

Chamamah Soeratno, ed.

2008 Keraton Yogya: Sejarah dan Warisan Budaya, Jakarta: PT. Indonesia Kebanggaanku.

Garraghan S.J., Gilbert J.

1957 A Guide to a Historical Method (New York: Fordham University Press.

Haryono Haryo Guritno

2006 Keris Jawa: Antara Mistik dan Nalar (Jakarta: PT. Indonesia Kebanggaanku, 2006). 
Hamzuri

1984 Keris, Jakarta: Penerbit Jambatan

Holt, Claire

2000 Melacak Jejak Perkembangan Seni di Indonesia, Terj. R.M. Soedarsono Bandung: Arti Line.

K.R.T. Gaura Mancacaritadipura,

2009 "Tanggung Jawab Tindak Lanjut Inskripsi Keris Indonesia pada daftar Representatif Budaya Takbenda Warisan Manusia Oleh UNESCO" Paper Diskusi Ilmiah Keris dalam Perspektif Keilmuan, Surakarta: Pusat Penelitian \& Pengembangan Kebudayaan Departemen Kebudayaan \&Pariwisata RI; ISI Surakarta.

Krisha Hutama Soesmoro

2010 "Keris Jawa Tradisional Di Daerah Yogyakarta dan Surakarta: Kontinuitas dan Perubahannya" Disertasi, Yogyakarta: UGM,

Kuntowijoyo

2006 Budaya dan Masyarakat, Yogyakarta: Tiara Wacana

Lombard, Denys

2005 Nusa Jawa: Silang Budaya Jaringan Asia Bagian II, Terj. Winarsih Partaningrat Arifin (Jakarta: Gramedia Pustaka Utama,

Munif Al Anshori

2009 Pustaka Keris: Khasanah Budaya Nusantara, Jakarta: PT. Pustaka Keris Indonesia, vol 17.

Mulder, Niels

1984 Kebatinan Dan Hidup Sehari-Hari Orang Jawa: Kelangsungan Dan. Perubahan Kulturil, Jakarta: Gramedia,
Pande Wayan Suteja Neka

2009 "Keris Dalam Perspektif Permuseuman", Paper Diskusi Ilmiah Keris Dalam Perspektif Keilmuan" (Surakarta: Pusat Penelitian \& Pengembangan Kebudayaan Departemen Kebudayaan \& Pariwisata RI; ISI Surakarta,).

R.D.S. Ranuwijaya

2009 "Dhapur Putut Kembar", Pusaka Keris, Jakarta: PT. Pustaka Keris Indonesia, Vol. 16,

Ricklefs, M.C.

2002 Yogyakarta di Bawah Sultan Mangkubumi 1749-1792: Sejarah Pembagian Jawa Terj. Hartono Hadikusumo \& E. Setiyawati Alkhatab (Yogyakarta: Matabangsa,).

SuwarsonoLumintu.

2004 Ilmu Keris (Yogyakarta: Naskah untuk Kalangan Sendiri).

Umar Kayam

1981 Seni, Tradisi, Masyarakat (Jakarta: Sinar Harapan).

Tony Rudyansah

2009 "Sebuah Logika Kultural tentang Keris", Paper Diskusi Ilmiah Keris Dalam Perspektif Keilmuan" (Surakarta: Pusat Penelitian \& Pengembangan Kebudayaan Departemen Kebu-dayaan \& Pariwisata RI; ISI Surakarta,).

\section{Sumber Wawancara}

Empu Sungkowo (62 tahun), cucu Empu Supowinangun, empu keris anak angkat sekaligus murid Empu Jeno Harumbrojo. 